\title{
Subcellular Localization and Properties of Partially Purified Dimethylamine and Trimethylamine Mono-oxygenase Activities in Candida utilis
}

\author{
By JEFFREY GREEN† AND PETER J. LARGE* \\ Department of Biochemistry, Unicersity of Hull, Hull HU6 $7 R X, U K$
}

(Receited 17 February 1984 ; retised 28 May 1984)

\begin{abstract}
By techniques involving differential centrifugation and specific precipitation with $\mathrm{CaCl}_{2}$, it was shown that dimethylamine and trimethylamine mono-oxygenase activities co-sediment with NADPH-cytochrome $c$ reductase activity in sphaeroplast lysates of Candida utilis grown on trimethylamine as sole nitrogen source. Since the active fraction also contained low levels of cytochromes $\mathrm{P}-450$ and $\mathrm{P}-\mathbf{4 2 0}$, it was concluded that the two amine mono-oxygenases are located in the smooth endoplasmic reticulum and thus end up in the microsomal fraction on cell fractionation. Ten to twenty-fold enrichment of mono-oxygenase specific activity could be achieved by separation of activity from soluble protein by centrifugation or gel filtration. Cellfree extracts prepared in the absence of FAD showed only very low mono-oxygenase activity for either substrate. Some activity could be restored by addition of flavin nucleotides: there was a fivefold stimulation by FAD and a fourfold stimulation by FMN. All trimethylamine monooxygenase activity was lost when a partially purified preparation containing both activities was incubated for more than $24 \mathrm{~h}$ at $0^{\circ} \mathrm{C}$, suggesting that separate enzymes are responsible for the oxidation of secondary and tertiary amines. The enzyme preparation oxidized a wide range of secondary alkylamines up to dibutylamine and tertiary alkylamines up to tributylamine. Primary amines, choline, di- and triethanolamine, spermine, spermidine and substituted anilines were not oxidized. NADH had a lower apparent $K_{m}$ value and higher $V_{\max }$ value than NADPH. Secondary and tertiary alkylamines containing more than one kind of alkyl group gave more than one kind of aldehyde on oxidation. Stoicheiometry determinations showed a consumption of 1 mol $\mathrm{NAD}(\mathrm{P}) \mathrm{H}$ and $1 \mathrm{~mol} \mathrm{O}_{2}$ per mol aldehyde formed. Carbon monoxide, cyanide, proadifen hydrochloride (SKF 525-A), mercurials and mercaptoethanol all inhibited both activities.
\end{abstract}

\section{INTRODUCTION}

In contrast to methylotrophic bacteria, where the diverse enzyme systems involved in the oxidation of di- and trimethylamine have been fairly well characterized (Large, 1981: Anthony, 1982), very little is known about the oxidation of these two compounds in yeasts. Many yeasts are able to use them (and also monomethylamine) as sole nitrogen source, though not as carbon source (Van Dijken \& Bos, 1981), but there have been few studies on the enzymic mechanisms involved. Micro-organisms able to use these amines as sole nitrogen source are said to be methazotrophic (Zatman. 1981). Yamada et al. (1976) showed that whole cells of the methazotrophic yeast Candida sp. WY-3 converted trimethylamine into dimethylamine and formaldehyde and $n$-butylmethylamine into $n$-butylamine and formaldehyde, but they were unable to find activity in cell-free extracts. We have shown that the presence of a low concentration of FAD is necessary in the buffer used to prepare the extract before monooxygenase activity for dimethylamine and trimethylamine can be demonstrated in Candida boidinii, C. utilis and several other yeast species (Green \& Large, 1983a).

† Present address: Department of Biological Sciences, University of Warwick. Coventry CVA 7AL. UK. 
Although the key enzymes for the oxidation of monomethylamine - methylamine oxidase and catalase - are derepressed under nitrogen-limiting conditions even in the absence of amines (Zwart \& Harder, 1983; Green \& Large, 1984), the expression of mono-oxygenase activity for dimethylamine and trimethylamine requires the presence of a secondary or tertiary alkylamine in the growth medium (Green \& Large, 1984). This is in contrast to the observations of Yamada et al. (1976) who found that trimethylamine could be oxidized by whole cells of Candida sp. WY3 grown on several different primary amines as sole nitrogen source. Mono-oxygenase activity for trimethylamine (and other tertiary alkylamines) is also induced in cells grown on secondary alkylamines, although there is evidence (see Green \& Large, 1983a and below) that separate enzymes are responsible for the oxidation of secondary and tertiary amines.

In the present paper, we show that the carbon monoxide-sensitive systems catalysing the oxidation of dimethylamine and trimethylamine in cell-free extracts of $C$. utilis are located in the microsomal cell fraction. We describe further properties of the enzymes and their separation from soluble protein. Candida utilis has recently been renamed Hansenula jadinii (Barnett et al., 1983), of which it is the asexual state. The original name will be used in this paper. Preliminary accounts of parts of these results have been published (Green \& Large, 1983b; Large \& Green, 1984).

\section{METHODS}

Materials. 2,4-Dichloro-6-phenylphenoxyethylamine (Lilly 53325) and its $N, N$-diethyl derivative (Lilly 18947) were gifts from Eli Lilly International, Indianapolis, USA; proadifen hydrochloride (SKF 525-A) was a gift of Smith, Kline and French, Welwyn Garden City, UK. Zymolyase 5000 was from Miles Laboratories, Stoke Poges, Slough, UK. Sepharose 2B and 4B were obtained from Pharmacia. Methylamine dehydrogenase (EC 1.4.99.3) was prepared from Pseudomonas AM1 as described by Boulton \& Large (1979). 4-Aminobutyl-Sepharose was prepared as described by Shaltiel \& Er-El (1973). Secondary amines were obtained from the sources listed in Eady et al. (1971) and tertiary amines from the sources in Boulton et al. (1974). Carbon monoxide came from BDH. All other chemicals were from Sigma or Fisons Scientific Apparatus.

Growth and maintenance of yeast cultures. Candida utilis NCYC 321 was grown and maintained as described by Haywood \& Large (1981), the carbon source being $55 \mathrm{~mm}$-glucose and the nitrogen source $30 \mathrm{~mm}$-trimethylamine hydrochloride. Growth was followed by measurement of optical density at $663 \mathrm{~nm}$. Cells were harvested by

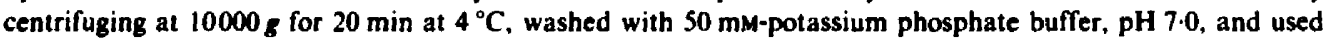
immediately.

Preparation of cell-free extracts. Cells were suspended in an equal volume of $50 \mathrm{~mm}$-potassium phosphate buffer. $\mathrm{pH} 7.0$, containing $20 \mu \mathrm{M}-\mathrm{FAD}$, and passed twice through a French pressure cell operated at $7.85 \mathrm{MPa}$. Unbroken cells were removed by centrifugation at $20000 \mathrm{~g}$ for $15 \mathrm{~min}$ at $4{ }^{\circ} \mathrm{C}$.

Enzyme assays. Dimethylamine and trimethylamine mono-oxygenase activity were measured by two methods. (a) The spectrophotometric method involved following decrease of absorbance at $340 \mathrm{~nm}$ and $25^{\circ} \mathrm{C}$ in polystyrene cuvetles $(1 \mathrm{~cm}$ light path) containing $67 \mu \mathrm{mol}$ potassium phosphate buffer $\mathrm{pH} 7.0,0.4 \mu \mathrm{mol} N A D(P) H, 5 \mu \mathrm{mol}$ dimethylamine or $10 \mu \mathrm{mol}$ trimethylamine hydrochloride and enzyme in a total volume of $3 \mathrm{ml}$. The reaction was started by addition of the amine after measuring any endogenous $N A D(P) H$ oxidation. One unit of enzyme is defined as the amount required to catalyse the amine-dependent oxidation of $1 \mu \mathrm{mol} N \mathrm{NAD}(\mathrm{P}) \mathrm{H} \mathrm{min}^{-1}$ under these conditions. (b) The formaldehyde-accumulation assay involved measuring formaldehyde formation from dior trimethylamine. The assay mixture was the same as (a) except that incubation was performed in test tubes and I $\mu \mathrm{mol}$ of NAD(P)H was used. Reaction was started by addition of enzyme and stopped by adding $0.2 \mathrm{ml}$ of $2.5 \mathrm{M}$ $\mathrm{HClO}_{4}$. After neutralization and centrifugation, the formaldehyde was determined. One enzyme unit is the amount required to catalyse the formation of $1 \mu \mathrm{mol}$ of formaldehyde $\min ^{-1}$. Catalase (EC1.11.1.6), methylamine oxidase and NADP-linked isocitrate dehydrogenase (EC1.1.1.42) were assayed as described by Haywood \& Large (1981). Malate dehydrogenase (ECI.1.1.37) was assayed by measuring the rate of decrease in absorbance at $340 \mathrm{~nm}$ when $200 \mu \mathrm{mol}$ phosphate buffer pH 7.5, $0.4 \mu \mathrm{mol}$ NADH and $15 \mu \mathrm{mol}$ oxaloacetate were incubated with enzyme (reaction volume $3 \mathrm{ml}$ ). NADPH-cytochrome $c$ reductase $(E C 1.6 .2 .4)$ and cytochrome oxidase (EC1 . 9.3.1) were assayed as described by Delaisse et al. (1981). Alkaline phosphatase (EC3.1.3.1) was assayed by measuring the rate of increase in absorbance at $412 \mathrm{~nm}$ when $200 \mu \mathrm{mol}$ Tris/ $/ \mathrm{HCl}$ buffer $\mathrm{pH} 8.0$ and $14.5 \mu \mathrm{mol} 4$-nitrophenyl phosphate were incubated with enzyme in a total volume of $3 \mathrm{ml}$. All assays were performed at $25^{\circ} \mathrm{C}$, and are averages of two determinations.

Preparation and lysis of sphaeroplasis. Exponential phase yeast cultures $\left(\mathrm{OD}_{003}=1.0\right)$ grown with trimethylamine as sole nitrogen source were harvested and washed in $70 \mathrm{mM}$-potassium phosphate buffer pH 7.5. Cells ( $5 \mathrm{~g}$ wet weight) were suspended in buffer $\mathrm{A}$ ( $70 \mathrm{mM}$-potassium phosphate, $\mathrm{pH} 7.5 ; \mathrm{MgCl}_{z} 1 \mathrm{mM}$. EDTA $1 \mathrm{~mm}$ ) containing $2 \mathrm{M}$-sorbitol. After $10 \mathrm{~min}$ osmotic stabilization at room temperature the cells were centrifuged 
at $10000_{\mathrm{g}}$ for $10 \mathrm{~min}$. The pellet thus obtained was resuspended in buffer A containing $2 \mathrm{M}$-sorbitol and $\mathrm{I} \mathrm{mg}$ Zymolyase $5000 \mathrm{ml}^{-1}$ to a concentration of $20 \mathrm{mg}$ wet weight of cells ml ${ }^{-1}$ (Osumi et al., 1975). Mercaptoethanol was omitted because it inhibits amine oxidase activity (Zwart et al., 1980). The cells were incubated at $30^{\circ} \mathrm{C}$ for about $1 \mathrm{~h}$, the formation of sphaeroplasts being followed under a phase contrast microscope. When sphaeroplast formation was complete, an equal volume of buffer $A$ was added, and the mixture left to stand in ice for $10 \mathrm{~min}$. The Zymolyase was then removed by two washes in buffer A containing I M-sorbitol. The sphaeroplasts were then lysed by diluting the sorbitol concentration of the suspension to $0.3 \mathrm{M}$ with buffer $\mathrm{A}$, followed by gentle shaking. Unbroken sphaeroplasts and debris were removed by centrifuging for $5 \mathrm{~min}$ at $1000 \mathrm{~g}$ and $4{ }^{\circ} \mathrm{C}$.

Cell-fractionation. The lysed sphaeroplasts were fractionated by differential centrifugation at $4^{\circ} \mathrm{C}$ as described by Delaissé et al. (1981). For details of centrifugation times and speeds, see legend to Table 1 . Mitochondria and peroxisomes in fraction $P_{2}$ were separated by the method of Bartels \& Jensen (1979). All the pellets were washed in $0.3 \mathrm{M}$-sorbitol in $10 \mathrm{~mm}$-potassium phosphate. $\mathrm{pH} 7.0$, containing $10 \mu \mathrm{M}-\mathrm{FAD}$ and resuspended in the same mixture before enzyme assays were performed.

Determination of kinetic parameters. $K_{m}^{2 p p}$ and $V_{\max }$ values were obtained by varying the amine (or electron donor) and its concentration in the spectrophotometric assay and plotting reciprocal rates against reciprocal concentrations. Lines were fitted by eye. One preparation was used for secondary amines, another for tertiary amines. Variation in the values obtained occurred from one preparation to another, but values were within one order of magnitude. Representative data like those in Table 2 are to allow comparison between substrates.

Chemical determinations. Formaldehyde was determined by the method of Nash (1953), protein by the method of Bradford (1976), dimethylamine by the method of Dubin (1960), methylamine by the enzymic method of Large $e t$ al. (1969), NAD(P)H spectrophotometrically at $340 \mathrm{~nm}$, and oxygen polarographically using a Rank oxygen electrode calibrated by the method of Robinson \& Cooper (1970). Trimethylamine was determined by the enzymic method of Large \& McDougall (1975), and total aldehyde by the method of Sawicki et al. (1961).

Determination of reaction stoicheiometry. (a) Spectrophotometric experiment. A normal spectrophotometric reaction mixture was set up except that approximately $0.1 \mu \mathrm{mol}$ dimethylamine or trimethylamine was used as substrate. When the reaction had gone to completion and the amount of NADH oxidized had been measured, $0.3 \mathrm{ml}$ of $2.5 \mathrm{M} \cdot \mathrm{HClO}_{4}$ was added. After neutralization and centrifugation, formaldehyde, trimethylamine, dimethylamine and methylamine were estimated. Two control reactions were run, the first containing boiled enzyme, the other containing no tri- or dimethylamine to monitor any substrate-independent NADH oxidation. (b) Polarographic experiment. A bout $0.1 \mu \mathrm{mol}$ tri- or dimethylamine was incubated with $0.6 \mu \mathrm{mol} N \mathrm{NDH}$ in the chamber of a calibrated oxygen electrode. The reaction was started by addition of enzyme and oxygen consumption followed to completion. Then $0.3 \mathrm{ml}$ of $2.5 \mathrm{M} \cdot \mathrm{HClO}_{4}$ was added, and after neutralization and centrifugation the formaldehyde formed was measured. Similar controls were performed as those in (a). The results in Table 4 are the differences between the test and the control. Experiments with standards suggested that the analytical measurements were accurate to about $10 \%$.

Inhibition experiments. Inhibitors were preincubated with enzyme in the assay mixture for 5 min in the absence of substrate before the reaction was started by substrate addition to a final concentration of $2 \mathrm{mM}$. In the case of dimethylamine mono-oxygenase the formaldehyde accumulation assay was used, whereas in the case of trimethylamine mono-oxygenase the spectrophotometric assay was used to eliminate effects of the inhibitors on dimethylamine mono-oxygenase activity.

Difference spectra. These were determined on a Pye-Unicam SP1800 recording spectrophotometer at $25^{\circ} \mathrm{C}$. Samples were reduced with dithionite or NADH and oxidized with ferricyanide.

\section{RESULTS}

\section{Subcellular fractionation of $C$. utilis}

The isolation of the subcellular components of $C$. utilis, grown with trimethylamine as the sole source of nitrogen, was achieved by differential centrifugation of osmotically lysed sphaeroplasts, following the general scheme of Delaisse et al. (1981). The marker enzymes were chosen on the basis of the results obtained by Delaissé et al. (1981). The results are shown in Table 1.

About half the total malate dehydrogenase activity sedimented, mainly in fraction $\mathbf{P}_{2}$ (material sedimenting after $5 \mathrm{~min}$ at $3500 \mathrm{~g}$ ), and this same fraction contained $94 \%$ of the total cytochrome $c$ oxidase activity. Malate dehydrogenase and cytochrome oxidase both had increased relative specific activities in the $P_{2}$ fraction (Table 1). Although cytochrome oxidase is a classical mitochondrial marker enzyme (Lloyd, 1974), malate dehydrogenase in yeasts can under some growth conditions occur in both mitochondria and peroxisomes (microbodies) (Zwart et al., 1983). As a result of the lysis procedure used, $75 \%$ of the catalase activity appeared 
Table 1. Distribution of marker enzymes in subcellular fractions prepared by differential centrifugation of lysed sphaeroplasts of Candida utilis

Relative amounts of each enzyme are the (amount in fraction) $\times$ (total amount recovered in all fractions) ${ }^{-1} \times 100$. Relative specific activities (in parentheses) are the (percentage of total recovered activity) $\times$ (percentage of total recovered protein $)^{-1}$. Recoveries are presented as a percentage relative to the sphaeroplast lysate, $S_{1} . P_{2}$ represents the pellet obtained by centrifuging the lysate $S_{1}$ for $S \mathrm{~min}$ at $3500 \mathrm{~g}$. $\mathrm{P}_{3}$ represents the pellet from centrifuging the supernatant from $P_{2}$ for $10 \mathrm{~min}$ at $12000 \mathrm{~g}$. Similarly $P_{4}$ and $P_{5}$ represent the pellets from centrifugation for $20 \mathrm{~min}$ at $25000_{g}$ and $70 \mathrm{~min}$ at $50000_{\mathrm{g}}$, respectively. $S_{\mathrm{s}}$ is the final supernatant.

\begin{tabular}{|c|c|c|c|c|c|c|c|c|}
\hline \multirow[b]{2}{*}{ Constituent } & \multirow{2}{*}{$\begin{array}{l}\text { Absolute amount } \\
\text { in fraction } S_{1} \\
\text { (units of enzyme } \\
\text { activity or } \mathrm{mg}_{\mathrm{g}} \\
\text { of protein) }\end{array}$} & \multicolumn{6}{|c|}{$\begin{array}{l}\text { Relative amounts in each fraction } \\
\text { (relative specific activities in parentheses) }\end{array}$} & \multirow{2}{*}{$\begin{array}{c}\text { Recovery } \\
(\%)\end{array}$} \\
\hline & & $\mathbf{S}_{\mathbf{I}}$ & $\mathbf{P}_{2}$ & $P_{3}$ & $P_{\star}$ & $\mathbf{P}_{5}$ & $\mathbf{S}_{\mathrm{s}}$ & \\
\hline Catalase & 12420 & $(0 \cdot 82)$ & $\begin{array}{l}18.4 \\
(2.97)\end{array}$ & $\begin{array}{c}3.7 \\
(1 \cdot 34)\end{array}$ & $\begin{array}{l}2 \cdot 3 \\
(0 \cdot 56)\end{array}$ & $\begin{array}{c}2.95 \\
(0.21)\end{array}$ & $\begin{array}{l}72 \cdot 5 \\
(1 \cdot 00)\end{array}$ & $95 \cdot 6$ \\
\hline $\begin{array}{l}\text { Methylamine } \\
\text { oxidase }\end{array}$ & 4.95 & $(0.83)$ & $\begin{array}{l}53 \cdot 1 \\
(8 \cdot 56)\end{array}$ & $\begin{array}{l}29 \cdot 5 \\
(7.07)\end{array}$ & $\begin{array}{c}0 \\
(0)\end{array}$ & $\begin{array}{c}0 \\
(0)\end{array}$ & $\begin{array}{l}27 \cdot 5 \\
(0 \cdot 38)\end{array}$ & $97 \cdot 1$ \\
\hline $\begin{array}{l}\text { Cytochrome } c \\
\text { oxidase }\end{array}$ & 8.62 & $(1 \cdot 06)$ & $\begin{array}{c}94 \cdot 2 \\
(15 \cdot 2)\end{array}$ & $\begin{array}{c}5 \cdot 8 \\
(2 \cdot 10)\end{array}$ & $\begin{array}{c}0 \\
(0)\end{array}$ & $\begin{array}{c}0 \\
(0)\end{array}$ & $\begin{array}{c}0 \\
(0)\end{array}$ & $125 \cdot 0$ \\
\hline $\begin{array}{l}\text { Malate } \\
\text { dehydrogenase }\end{array}$ & 44.8 & $(1 \cdot 00)$ & $\begin{array}{l}39 \cdot 7 \\
(6 \cdot 40)\end{array}$ & $\begin{array}{c}4 \cdot 76 \\
(1 \cdot 72)\end{array}$ & $\begin{array}{c}3 \cdot 3 \\
(0 \cdot 80)\end{array}$ & $\begin{array}{c}5 \cdot 53 \\
(0 \cdot 39)\end{array}$ & $\begin{array}{l}46 \cdot 7 \\
(0 \cdot 65)\end{array}$ & $118 \cdot 0$ \\
\hline $\begin{array}{l}\text { NADPH-cytochrome } c \\
\text { reductase }\end{array}$ & 1.98 & $(0.74)$ & $\begin{array}{c}0 \\
(0)\end{array}$ & $\begin{array}{c}0 \\
(0)\end{array}$ & $\begin{array}{c}0 \\
(0)\end{array}$ & $\begin{array}{l}23 \cdot 7 \\
(1 \cdot 68)\end{array}$ & $\begin{array}{l}76 \cdot 3 \\
(1 \cdot 06)\end{array}$ & 87.4 \\
\hline $\begin{array}{l}\text { Trimethylamine } \\
\text { mono-oxygenase }\end{array}$ & 0.17 & $(1.07)$ & $\begin{array}{c}0 \\
(0)\end{array}$ & $\begin{array}{c}0 \\
(0)\end{array}$ & $\begin{array}{l}31 \cdot 1 \\
(7 \cdot 59)\end{array}$ & $\begin{array}{l}68 \cdot 9 \\
(4 \cdot 89)\end{array}$ & $\begin{array}{l}0 \\
0\end{array}$ & $125 \cdot 0$ \\
\hline $\begin{array}{l}\text { Dimethylamine } \\
\text { mono-oxygenase }\end{array}$ & $4 \cdot 52$ & $(0.79)$ & $\begin{array}{c}0 \\
(0)\end{array}$ & $\begin{array}{c}0 \\
(0)\end{array}$ & $\begin{array}{l}17 \cdot 7 \\
(4 \cdot 32)\end{array}$ & $\begin{array}{l}74 \cdot 5 \\
(5 \cdot 28)\end{array}$ & $\begin{array}{c}7.8 \\
(0 \cdot 11)\end{array}$ & $92 \cdot 7$ \\
\hline $\begin{array}{l}\text { Alkaline } \\
\text { phosphatase }\end{array}$ & 5.60 & $(0.90)$ & $\begin{array}{c}0 \\
(0)\end{array}$ & $\begin{array}{c}0 \\
(0)\end{array}$ & $\begin{array}{c}0 \\
(0)\end{array}$ & $\begin{array}{c}0 \\
(0)\end{array}$ & $\begin{array}{l}100 \\
(1 \cdot 39)\end{array}$ & 105.0 \\
\hline $\begin{array}{l}\text { Isocitrate dehydrogenase } \\
\text { (NADP-linked) }\end{array}$ & 5.02 & $(0.76)$ & $\begin{array}{c}0 \\
(0)\end{array}$ & $\begin{array}{c}0 \\
(0)\end{array}$ & $\begin{array}{c}0 \\
(0)\end{array}$ & $\begin{array}{l}13.3 \\
(0.94)\end{array}$ & $\begin{array}{l}86 \cdot 7 \\
(1 \cdot 24)\end{array}$ & $89 \cdot 1$ \\
\hline Protein & 109 & & 6.2 & $2 \cdot 76$ & $4 \cdot 1$ & $14 \cdot 1$ & $72 \cdot 0$ & 117.3 \\
\hline
\end{tabular}

in the $\mathrm{S}_{5}$ (soluble) fraction, but of the $25 \%$ which sedimented, most was found in fractions $\mathrm{P}_{2}$ and $P_{3}$ (the latter sedimented in $10 \mathrm{~min}$ at $12000 \mathrm{~g}$ ), with enhanced specific activity in both fractions. The majority of methylamine oxidase activity $(73 \%)$ was also sedimented in these two fractions, again with increased relative specific activity. Catalase is a marker for yeast peroxisomes and $80 \%$ of the catalase activity of $C$. tropicalis is known to be peroxisomal (Yamada et al., 1982). Since cytoplasmic catalase has not been observed in $C$. utilis (Veenhuis et al., 1983) it seems likely that, as in the case of cell fractionation of Saccharomycopsis lipolytica (Delaissé et al., 1981) and $C$. stellatoidea (Jenkins et al., 1983), catalase is leaking from the peroxisomes. A similar explanation might also apply to all or some of the malate dehydrogenase found in the soluble fraction $S_{5}$.

Clearly fraction $P_{2}$ and to a lesser extent $P_{3}$ contained both mitochondrial and peroxisomal material. A separation was achieved by the procedure of Bartels \& Jensen (1979), in which resuspended $P_{2}$ material was layered over $50 \%(w / v)$ sucrose and centrifuged for $30 \mathrm{~min}$ at $50000 \mathrm{~g}$. The peroxisomes are sedimented by this method while the mitochondria remain at the buffer-sucrose interface. It was found that $98 \%$ of the methylamine oxidase of fraction $P_{2}$ and $99 \%$ of the catalase activity sedimented, while $99 \%$ of the cytochrome oxidase remained at the interface. This confirms the peroxisomal location of methylamine oxidase as already established in $C$. utilis by cytochemical staining techniques (Zwart et al., 1980).

NADPH-cytochrome $c$ reductase as well as trimethylamine and dimethylamine monooxygenases were found in the $P_{s}$ fraction (sedimenting after $70 \mathrm{~min}$ at $50000 \mathrm{~g}$ ) with increased relative specific activity (Table 1 ). A small (0.004) cytochrome $P-450$ peak was observed in this fraction, as measured by (reduced-plus-CO minus reduced) difference spectra. Similar spectra 
showed a peak at $422 \mathrm{~nm}$ in fractions $P_{4}(0.016), P_{5}(0.024)$ and $S_{5}(0.010)$, where the figures in parentheses give the absorbance at $422 \mathrm{~nm}$ (mg protein) $)^{-1}$. The distribution of these components suggests that trimethylamine and dimethylamine mono-oxygenases are located in the smooth endoplasmic reticulum of the cell (Delaissé et al., 1981) for which cytochrome P-450 and NADPH-cytochrome $c$ reductase are enzymic markers. This proposal is supported by the specific precipitation of the microsomal fraction of $C$. utilis with calcium chloride by the procedure of Käppeli et al. (1982). Of the activities in sonically lysed sphaeroplast extracts, $90 \%$ of the dimethylamine mono-oxygenase, $100 \%$ of the trimethylamine mono-oxygenase and $88 \%$ of the NADPH-cytochrome $c$ reductase activity could be precipitated by $16 \mathrm{~mm}$-calcium chloride.

Although $76 \%$ of the NADPH-cytochrome $c$ reductase activity appeared in the 'soluble' $S_{5}$ fraction (Table 1 ), its relative specific activity was not increased and about $30 \%$ of the activity could be sedimented by further centrifuging for $1 \mathrm{~h}$ at $100000 \mathrm{~g}$, while no alkaline phosphatase or NADP-linked isocitrate dehydrogenase activity was sedimented by this procedure. This suggests that the NADPH-cytochrome $c$ reductase is associated with very finely broken-up fragments of membrane.

The $S_{5}$ fraction contained more than $70 \%$ of the $S_{1}$ total of alkaline phosphatase, isocitrate dehydrogenase (NADP-linked) and protein, together with $47 \%$ of the malate dehydrogenase activity, the two former enzymes having somewhat increased relative specific activity (Table 1 ). The NADP-linked isocitrate dehydrogenase may be considered to mark the soluble fraction of the cell. Although alkaline phosphatase is found in the vacuoles of Saccharomyces cerevisiae (Holley \& Kidby, 1973) and C. utilis (Veenhuis et al., 1980), vacuoles are fragile structures and their contents may have been released during lysis of the sphaeroplasts.

\section{Partial purification of dimethylamine and trimethylamine mono-oxygenase activity}

Mono-oxygenase activity for both dimethylamine and trimethylamine was enriched by approximately 10 to 20 -fold by either of two procedures. In one, a crude extract (previously centrifuged at $20000 \mathrm{~g}$ for $15 \mathrm{~min}$ ) was then centrifuged at $150000 \mathrm{~g}$ for $60 \mathrm{~min}$ at $4{ }^{\circ} \mathrm{C}$ to yield a pellet containing all the dimethylamine and trimethylamine mono-oxygenase activity. After resuspension in $10 \mathrm{~mm}$-potassium phosphate, $\mathrm{pH} 7 \cdot 0$, containing $10 \mu \mathrm{M}-\mathrm{FAD}$ and recentrifuging, the pellet was free of methanol oxidase, alcohol dehydrogenase and NADH-formaldehyde reductase activity (which was probably similar to that observed by Hou et al., 1982). Alternatively, the crude extract was applied to a column $(10 \mathrm{~cm} \times 2 \mathrm{~cm}$ diam. ) of Sepharose $2 \mathrm{~B}$, equilibrated in $10 \mathrm{~mm}$-potassium phosphate, $\mathrm{pH} 7 \cdot 0$, containing $10 \mu \mathrm{M}-\mathrm{FAD}$, and eluted with the same buffer. The excluded fractions containing the activity were immediately applied to a column $(6 \mathrm{~cm} \times 1 \mathrm{~cm}$ diam.) of 4-aminobutyl-Sepharose 4B in the same buffer, to which the activity did not bind. The combined active fractions from this column typically had a specific activity of 0.22 units ( $\mathrm{mg}$ protein $)^{-1}$ and could be stabilized by adding bovine serum albumin to a concentration of $5 \mathrm{mg} \mathrm{ml}^{-1}$. Purification factors of up to 20-fold were achieved. On polyacrylamide gel electrophoresis of $100 \mu \mathrm{g}$ of protein on $4 \%$ or $7 \%$ gels, no proteins entered the gel. This fact, taken together with the exclusion from Sepharose $2 B$ and the sedimentation at $150000 \mathrm{~g}$, suggests that the activity was membrane-bound. Attempts to purify the system further were unsuccessful, and further purification will clearly require prior solubilization of the enzyme activity.

The enzyme preparation had a pH optimum of 7.0 for the oxidation of both dimethylamine and trimethylamine. The activity was stable at $4{ }^{\circ} \mathrm{C}$ for $40 \mathrm{~min}$ within the $\mathrm{pH}$ range 4 to 10 (dimethylamine) or 5 to 9 (trimethylamine). Beyond these limits, activity was rapidly lost.

\section{Effect of addition of flatin nucleotides}

Partially purified dimethylamine mono-oxygenase was prepared in the absence of FAD and showed a much reduced capacity to degrade dimethylamine. In the spectrophotometric assay, FAD stimulated the activity of the enzyme more than fivefold and FMN almost fourfold (Fig. 1). No synergistic effect was observed when the concentration of FAD was increased in the presence of $0.76 \mu \mathrm{M}-\mathrm{FMN}$. With trimethylamine mono-oxygenase activity, $40 \mathrm{nM}-\mathrm{FAD}$ 


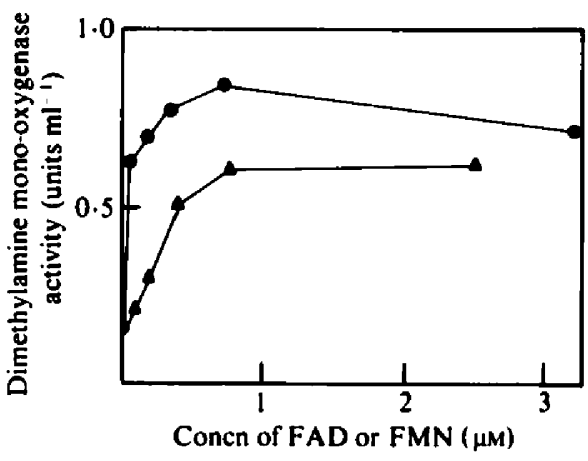

Fig. I

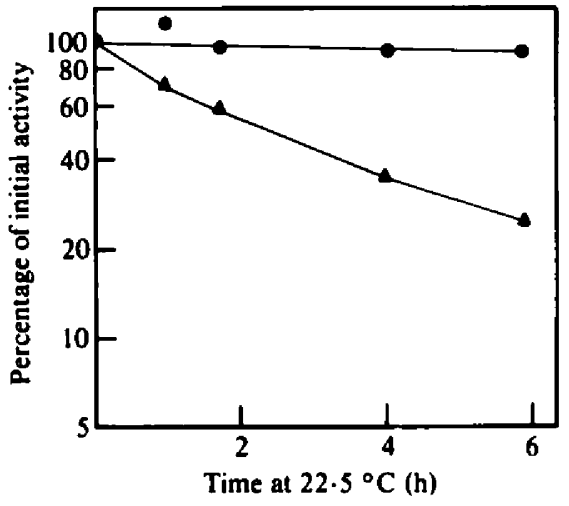

Fig. 2

Fig. 1. Effect of flavin nucleotides on the rate of dimethylamine oxidation by partially purified dimethylamine mono-oxygenase of Candida utilis prepared in the absence of FAD. The effect of adding FAD or FMN to the enzyme was measured in the spectrophotometric assay. . Effect of FAD; $\Delta$, effect of FMN (Sigma grade I). The protein concentration of the enzyme was $1.22 \mathrm{mg} \mathrm{ml}^{-1}$.

Fig. 2. Relative stabilities of dimethylamine and trimethylamine mono-oxygenases of Candida urilis. Partially purified enzyme ( $3.1 \mathrm{mg}$ protein $\mathrm{ml}^{-1}$ ) was incubated at $22.5^{\circ} \mathrm{C}$ and samples were removed at intervals, and the activity measured in the spectrophotometric assay with dimethylamine $(O)$ or trimethylamine $(\Delta)$ as substrate; $100 \%$ activity was about 0.1 unit (mg protein) $)^{-1}$ for trimethylamine mono-oxygenase and $\mathbf{0 . 2}$ unit (mg protein) ${ }^{-1}$ for dimethylamine mono-oxygenase.

stimulated activity threefold and $2.8 \mu \mathrm{M}-\mathrm{FMN}$ stimulated activity twofold (at a protein concentration of $3.1 \mathrm{mg} \mathrm{ml}^{-1}$ ). The activity reconstituted in this way was still significantly lower than in extracts prepared by breaking open cells suspended in buffer containing FAD.

\section{Are the dimethylamine and trimethylamine mono-oxygenases separate enzymes?}

Although many of the properties of dimethylamine mono-oxygenase and trimethylamine mono-oxygenase were very similar, the two amine oxidation systems showed a 90 -fold difference in sensitivity to inhibition by carbon monoxide in whole cells of $C$. boidinii (Green \& Large, 1983a), trimethylamine mono-oxygenase being the more sensitive. They also showed a significant difference in stability. When a partially purified preparation containing both activities (which co-purified) was incubated for several hours at $22.5^{\circ} \mathrm{C}$, the trimethylamine mono-oxygenase activity proved to be much less stable (Fig. 2), and at $35^{\circ} \mathrm{C}$ the former enzyme had a half-life of $1.7 \mathrm{~min}$ (protein concentration $1.5 \mathrm{mg} \mathrm{ml}^{-1}$ ), while at $37^{\circ} \mathrm{C}$ the latter had a half-life of only $0.4 \mathrm{~min}$ (protein concentration $5.7 \mathrm{mg} \mathrm{ml}^{-1}$ ). A preparation which had been left in ice for more than $24 \mathrm{~h}$ effectively lost all trimethylamine mono-oxygenase activity. Thus it was possible to obtain dimethylamine mono-oxygenase free of trimethylamine mono-oxygenase activity, but not vice versa.

\section{Properties of the partially purified enzyme preparation}

The enzyme preparation was specific for secondary and tertiary amines. Primary amines and quaternary ammonium derivatives (tetramethylammonium and choline) were not oxidized. Apparent $K_{m}$ and $V_{\max }$ values for active substrates are given in Table 2. Other tertiary amine substrates additional to those in Table 2 included tripropylamine, tributylamine and the amines in Table 3 (see below). The following secondary and tertiary amines were not oxidized: diethanolamine, $N$-methylaniline, sarcosine, spermine, spermidine, $N N$-dimethylaniline, and triethanolamine.

With respect to electron donors, NADH and NADPH were both active. NADH was shown to be the more efficient donor with a $V_{\max }$ of 0.128 units (mg protein) ${ }^{-1}$ and a $K_{m}^{\text {app }}$ of $28.5 \mu \mathrm{M}$ compared to a $V_{\max }$ of 0.03 units (mg protein) ${ }^{-1}$ and a $K_{\mathrm{m}}^{\text {app }}$ of $166 \mu \mathrm{M}$ for NADPH. The ratios $V_{\text {max }} / K_{\mathrm{m}}^{\text {app }}$ are thus 4.5 for NADH and 0.18 for NADPH (concentrations in mM). Accordingly, in 
Table 2. Kinetic parameters for the secondary-amine mono-oxygenase of Candida utilis

These were measured with partially purified enzyme in the spectrophotometric assay with NADH as the electron donor, at $\mathrm{pH} 7.0$ and $25^{\circ} \mathrm{C}$. A separate preparation was used for the tertiary amines. Double reciprocal plots of rate and concentration were used in the evaluation. Values are representative (see Methods).
Substrate
$K_{\mathrm{m}}^{\text {app }}$
$(\mu \mathrm{M})$
$\left[\begin{array}{c}V_{\max } \\ \text { [Units (mg protein) }\end{array}{ }^{-1}\right.$ ]
$V_{\max } / K_{m}^{a p p}$
[Units (mg protein) ${ }^{-1} \mathrm{mM}^{-1}$ ]

Secondary amines

Dimethylamine

Diethylamine

Dipropylamine

Dibutylamine

36.8

$21 \cdot 7$

303

Methylethylamine

$28 \cdot 3$

$93 \cdot 0$

Methylpropylamine

80.0

278

Methylbutylamine

$29 \cdot 4$

$70 \cdot 4$

Methyloctylamine

Methylethanolamine

654

833

Ethylpropylamine

833
125

Ethylbutylamine

Propylbutylamine

800

Tertiary amines

Trimethylamine

Dimethylethylamine

Diethylmethylamine

Triethylamine

$1 \cdot 18$
$4 \cdot 0$
$0 \cdot 833$
$4 \cdot 44$

$0 \cdot 220$

$0 \cdot 225$

0.114

0.058

$0 \cdot 310$

$0 \cdot 263$

0.179

0.080

0.057

0.270

0.222

$0 \cdot 340$

$0 \cdot 370$

5.98

10.37

0.376

2.05

3.33

3. 29

0.664

$2 \cdot 72$

0.812

0.413

0.267

$2 \cdot 72$

0.463

0.022

0.079

$0 \cdot 105$

0.033

Table 3. Formation of aldehydes from secondary amines by the partially purified amine monooxy'genases of Candida utilis

Total aldehyde formed was measured by the method of Sawicki et al. (1961) and formaldehyde separately by the acetylacetone method (Nash. 1953).

Substrate

Secondary amines

Dimethylamine

Methylethylamine

Methylpropylamine

Methylisopropylamine

Methylbutylamine

Methyloctylamine

Methylbenzylamine

Tertiary amines

Trimethylamine

Dimethylethylamine

Dimethyl-2-chloroethylamine

Dimethylaminoethanol

1-Dimethylamino-2-propano]

3-Dimethylamino-1-propanol

Dimethylbenzylamine

Dimethylcyclohexylamine

Dimethyldodecylamine

Diethylmethylamine

Dibutylmethylamine
Formaldehyde as ${ }^{\circ}$ : of the total aldehyde

most experiments NADH was used, except where the rate of substrate-independent NADH oxidation was too high to be acceptable.

The $K_{\mathrm{m}}$ for oxygen could not be determined, since it was below the level of accurate polarographic measurement.

Mono-oxygenase attack on secondary and tertiary amines containing more than one kind of alkyl group gave rise to more than one kind of aldehyde (Table 3). The other aldehydes formed in this experiment were not further investigated. 
Table 4. Stoicheiometry of the dimethylamine and trimethylamine mono-oxygenase reactions

Experiments 1 and 3 were spectrophotometric, experiments 2 and 4 were polarographic. For experimental details, see Methods section. The values represent substrate consumed or product formed (nmol).

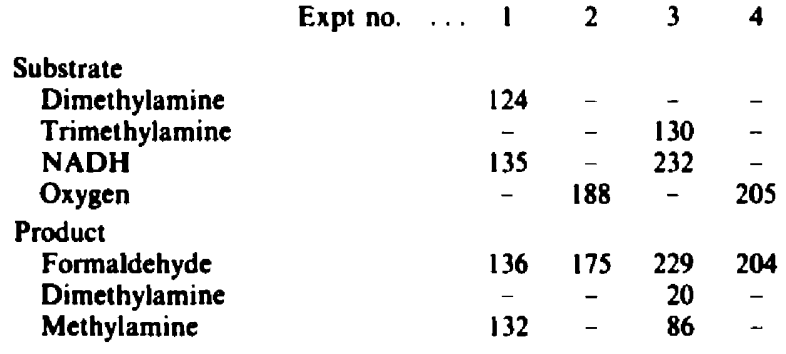

Table 5. The effect of various inhibitors of the dimethylamine mono-oxygenase and trimethylamine mono-oxygenase of $C$. utilis

Inhibitors were present for a 5 min pre-incubation period in the complete assay system in the absence of the amine substrate. Substrate concentration was $2 \mathrm{mM}$. Dimethylamine mono-oxygenase was measured by the formaldehyde accumulation assay, trimethylamine mono-oxygenase by the spectrophotometric method. ND, Not done.

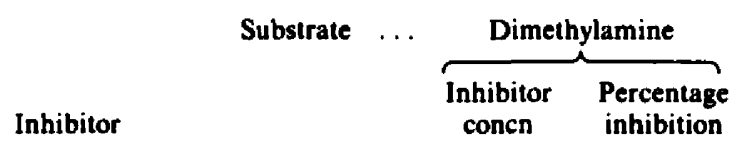

Lilly 53325

Lilly 18947

Tetramethylammonium chloride trans-2-Phenylcyclopropylamine

Harmaline hydrochloride

Pargyline hydrochloride

Aminoacetonitrile

Disodium EDTA

Cuprizone

2,2'-Bipyridyl

Potassium cyanide

Carbon monoxide

Hydroxylammonium chloride

Sodium azide

Proadifen hydrochloride

Metyrapone

Iodoacetamide

$N$-Ethylmaleimide

Sodium p-hydroxymercuribenzoate

Sodium mersalyl

Mercaploethanol

$\begin{array}{lc}0.5 \mathrm{mM} & 65.6 \\ \text { ND } & \\ 5 \mathrm{mM} & 20.7 \\ 0.25 \mathrm{mM} & 60.6 \\ \text { ND } & \\ 1.16 \mathrm{mM} & 15.7 \\ 0.1 \mathrm{mM} & 0 \\ 2.5 \mathrm{mM} & 9.8 \\ 12.5 \mathrm{MM} & 4.9 \\ 0.5 \mathrm{mM} & 12.7 \\ 0.5 \mathrm{mM} & 78.7 \\ 30 \mathrm{~s} & 100 \\ \text { bubbling } & 99 \\ 0.5 \mathrm{mM} & 14.6 \\ 5 \mathrm{mM} & 71.7 \\ 0.5 \mathrm{mM} & 0 \\ 1.0 \mathrm{mM} & 0 \\ 1.25 \mathrm{mM} & 2 \\ 1.25 \mathrm{mM} & 94.1 \\ 0.2 \mathrm{mM} & 96.4 \\ 0.5 \mathrm{mM} & 67.3 \\ 0.5 \mathrm{mM} & \end{array}$

$\overbrace{\begin{array}{c}\text { Inhibitor } \\ \text { concn }\end{array} \quad \begin{array}{c}\text { Percentage } \\ \text { inhibition }\end{array}}^{\text {Trimethylamine }}$

$\begin{array}{lc}0.33 \mathrm{mM} & 28.3 \\ 0.33 \mathrm{mM} & 50.0 \\ 6.0 \mathrm{mM} & 45.0 \\ 3.3 \mathrm{mM} & 0 \\ 0.66 \mathrm{mM} & 0 \\ 0.66 \mathrm{mM} & 100 \\ \text { ND } & \\ 3.0 \mathrm{mM} & 0 \\ 15 \mathrm{\mu M} & 27.6 \\ 0.6 \mathrm{mM} & 0 \\ \text { ND } & \\ 30 \mathrm{~s} & 100 \\ \text { bubbling } & 100 \\ 1.2 \mathrm{mM} & \\ \text { ND } & 53.0 \\ 0.33 \mathrm{mM} & 52.2 \\ \text { I.16 mM } & \\ \text { ND } & \\ \text { ND } & 97.4 \\ 0.24 \mathrm{mM} & \\ \text { ND } & \\ \text { ND } & \end{array}$

Determination of the reactants consumed and products formed (Table 4) showed that the stoicheiometry of the two oxidations is

$$
\begin{aligned}
& \left(\mathrm{CH}_{3}\right)_{3} \mathrm{NH}^{+}+\mathrm{NAD}(\mathrm{P}) \mathrm{H}+\mathrm{H}^{+}+\mathrm{O}_{2} \rightarrow\left(\mathrm{CH}_{3}\right)_{2} \mathrm{NH}_{2}{ }^{+}+\mathrm{NAD}(\mathrm{P})^{+}+\mathrm{HCHO}+\mathrm{H}_{2} \mathrm{O} \\
& \left(\mathrm{CH}_{3}\right)_{2} \mathrm{NH}_{2}{ }^{+}+\mathrm{NAD}(\mathrm{P}) \mathrm{H}+\mathrm{H}^{+}+\mathrm{O}_{2} \rightarrow \mathrm{CH}_{3} \mathrm{NH}_{3}{ }^{+}+\mathrm{NAD}(\mathrm{P})^{+}+\mathrm{HCHO}+\mathrm{H}_{2} \mathrm{O}
\end{aligned}
$$

Some differences were observed in the sensitivity of the two enzymes to different inhibitors (Table 5). In addition to the compounds listed, divalent cations at $0.1 \mathrm{mM}\left(\mathrm{Co}^{2+}, \mathrm{Fe}^{2+}, \mathrm{Mn}^{2+}\right.$ and $\mathrm{Zn}^{2+}$ - all potent inhibitors of bacterial dimethylamine mono-oxygenase) failed to inhibit the enzyme. The only inhibitors to be examined kinetically were carbon monoxide and potassium cyanide. $\mathrm{CO}$ inhibited both dimethylamine and trimethylamine oxidation 
uncompetitively with $K_{i}$ values of respectively $7.5 \mu \mathrm{M}$ and $0.35 \mu \mathrm{M}$. Cyanide inhibition was also uncompetitive with $K_{i}$ values of $0.9 \mathrm{mM}$ and $0.8 \mathrm{~mm}$, respectively.

The (NADH-reduced minus oxidized) difference spectrum of the enzyme preparation showed absorption maxima at $444 \mathrm{~nm}$ and $426 \mathrm{~nm}$. Addition of excess dimethylamine bleached these peaks after $5 \mathrm{~min}$. The (dithionite-reduced-plus- $\mathrm{CO}$ minus reduced) difference spectrum had a peak at $422 \mathrm{~nm}$ and a shoulder at $446 \mathrm{~nm}$.

\section{DISCUSSION}

Previous studies on yeasts capable of oxidizing secondary and tertiary amines (Yamada et al., 1976) failed to detect any enzyme activity in cell-free extracts. The key to the discovery of the two amine mono-oxygenases was the addition of FAD to the cell-breakage buffer. FAD appeared to have two effects in that it partially stabilized the amine mono-oxygenase activities as well as stimulating them. Supplementation of dimethylamine mono-oxygenase with FAD never resulted in the same level of activity as that obtained when FAD was present in the cellbreakage buffer, indicating some irreversible inactivation of the apoenzyme'. FMN could replace FAD, but it was not as effective. The addition of FAD to a number of analogous systems such as the alkyl arylamine mono-oxygenase of pig-liver microsomes (Pettit et al., 1964) and the $\omega$-hydroxylase system of Saccharomycopsis lipolytica (Delaissé et al., 1981) stimulates or reactivates their respective activities. These observations suggest that FAD (and/or FMN) are probably constituents of the secondary and tertiary amine mono-oxygenase systems of yeasts. Other enzymes capable of oxidizing trimethylamine or dimethylamine, such as dehydrogenases (Colby \& Zatman, 1973; Meiberg \& Harder, 1978) and oxidases (Tipton, 1980) were not detected in $C$. utilis or $C$. boidinii.

No significant differences have been found between the amine mono-oxygenase systems of $C$. utilis and the previously studied systems of $C$. boidinii (Green \& Large, 1983a, 1984) except that there are higher levels of enzyme activity in C. utilis (Green \& Large, 1983a). The data presented here show that the amine mono-oxygenases are almost certainly located in the smooth endoplasmic reticulum, as they are found in the microsomal fraction $\left(\mathrm{P}_{5}\right)$ along with NADPHcytochrome $c$ reductase on disruption of yeast sphaeroplasts.

The stoicheiometry of trimethylamine and dimethylamine oxidation is in accordance with that of a mono-oxygenase (mixed-function oxidase), equations (1) and (2). Of the products of the reactions, methylamine is oxidized by methylamine oxidase and formaldehyde is degraded by a glutathione-dependent formaldehyde dehydrogenase (Green \& Large, 1984). The degradation products of trimethylamine and $N$-methylbutylamine were in agreement with the results obtained by Yamada et al. (1976) with whole-cell suspensions. Methylamine oxidation and the removal of the resulting $\mathrm{H}_{2} \mathrm{O}_{2}$ by catalase take place in the peroxisomes. It may be presumed that the oxidation of formaldehyde takes place in the cytosolic fraction of the cell (Sahm et al., 1975; Tanaka et al., 1976; Veenhuis et al. 1983) and it is thus evident that the process of obtaining nitrogen from methylated amines must involve a good deal of shuttling of metabolites from one subcellular compartment to another (Large \& Green, 1984). This is a common phenomenon where peroxisomes are involved in metabolic pathways (see Huang et al., 1983).

The $K_{\mathrm{m}}$ for oxygen of the dimethylamine mono-oxygenase was too low to be measured. The very low $K_{\mathrm{m}}$ values for oxygen of the amine mono-oxygenases and methylamine oxidase (Haywood \& Large, 1981) allow methazotrophic yeasts to utilize amines as nitrogen source in almost anaerobic conditions, in contrast to the situation of growth of yeasts on methanol, which is very slow at low oxygen concentrations (Veenhuis et al., 1983).

The two main pieces of evidence indicating that two separate mono-oxygenases are required for the oxidation of trimethylamine and dimethylamine are $(a)$ the different stability of the two activities (Fig. 2) and (b) their different sensitivity to inhibition by carbon monoxide, as shown by a 20 -fold difference in $K_{1}$ (see text) and a 90 -fold difference in partition constant in whole cells (Green \& Large, 1983a).

The substrate specificity observed by us agrees with the incomplete whole cell data of Yamada et al. (1976). Generally when we compare the yeast system with the dimethylamine mono- 
oxygenase of Pseudomonas aminovorans (Eady et al., 1971) and the trimethylamine monooxygenase of the same bacterium (Boulton et al., 1974), we see a broader specificity in the yeast enzymes, which show activity with amines that contain two or three alkyl groups with a carbon chain length of $\mathrm{C}_{3}$ or greater, and a lack of substrate inhibition which was found with both bacterial enzymes at amine concentrations above $1 \mathrm{mM}$. Bacterial trimethylamine monooxygenase is an $\mathrm{N}$-hydroxylase rather than a $\mathrm{C}$-hydroxylase (Bickel, 1971) and so forms trimethylamine $\mathrm{N}$-oxide as product rather than dimethylamine and formaldehyde (Boulton $\mathrm{et}$ al., 1974). Consequently the two trimethylamine mono-oxygenases show quite different properties, most importantly the insensitivity of the bacterial enzyme to carbon monoxide, cyanide and proadifen hydrochloride. Differences between the bacterial and yeast amine monooxygenases are further discussed by Large \& Green (1984).

Since trimethylamine $N$-oxide is probably not an intermediate in trimethylamine degradation in yeasts, and since no enzyme (reductase or demethylase) has been detected which can catalyse its metabolism, even in yeasts grown on trimethylamine $\mathbf{N}$-oxide as nitrogen source, its metabolism remains to be clarified. Similar negative results were obtained by Yamada et al. (1976). It seems probable that it must first be reduced to trimethylamine and then demethylated via the two mono-oxygenases described here. $\mathrm{N}$-Oxide reductases are difficult enzymes to study, since they are often inhibited by oxygen at relatively low concentrations (Hlavica, 1982).

When secondary amines containing both methyl and other alkyl groups are oxidized by yeast dimethylamine mono-oxygenase, the aldehyde products arise from both alkyl groups, as observed also with the bacterial enzyme (Eady et al., 1971). There is some evidence that the primary amine product may be matched to the substrate 'preferences' of methylamine oxidase.

The spectral studies, performed with partially purified dimethylamine mono-oxygenase from C. utilis should be treated cautiously, since there are a number of other microsomal activities present in the preparations. The absorption peaks (at $426 \mathrm{~nm}$ and $444 \mathrm{~nm}$ ) in the (reduced minus oxidized) difference spectrum and in the (reduced-plus-CO minus reduced) difference spectrum (at $422 \mathrm{~nm}$ ) provided little evidence for the presence of a cytochrome P-450 component. However, the extreme $\mathrm{CO}$ sensitivity of the system suggests that such an entity may be involved. The failure to detect cytochrome P-450 in C. utilis is not new (Kärenlampi et al., 1980) and it may be that a cytochrome P-420, similar to that found in the bacterial secondary amine monooxygenase (Eady et al., 1971), is in fact an active cytochrome and not merely denatured cytochrome P-450, as has been widely accepted. The shift and enhancement of the $426 \mathrm{~nm}$ peak to $422 \mathrm{~nm}$ in the spectrum of the reduced carbon monoxide-treated sample is very similar to observations made with the secondary-amine mono-oxygenase of Pseudomonas aminovorans (Eady et al., 1971), where evidence of an active P-420 cytochrome is very good (Brook \& Large, 1975).

We thank J. P. van Dijken and K. B. Zwart for valuable discussions, G. W. Haywood for help with the diagrams, and the Science and Engineering Research Council for support (grant B/23687).

\section{REFERENCES}

ANTHONy, C. (1982). The Biochemistry of Methylotrophs, pp. 195-218. London: Academic Press.

Barnett, J. A., Payne, R. W. \& Yarrow, D. (1983). Yeasts: Characteristics and Identification, pp. 317318. Cambridge: Cambridge University Press.

BARTELS, P. D. \& Jensen, P. K. (1979). Role of AMP in regulation of the citric acid cycle in mitochondria from bakers ${ }^{\circ}$ yeast. Biochimica et biophysica acta $\mathbf{5 8 2}$. 246-259.

BiCKEL, M. H. (1971). N-Oxide formation and related reactions in drug metabolism. Xenobiotica 1, 313319.

Boulton, C. A. \& Large, P. J. (1979). Properties of Pseudomonas AMI primary-amine dehydrogenase immobilized on agarose. Biochimica et biophysica acta 570, 22-30.
Boulton, C. A., Crabbe, M. J. C. \& large, P. J. (1974). Microbial oxidation of amines. Partial purification of a trimethylamine mono-oxygenase from Pseudomonas aminovorans and its role in growth on trimethylamine. Biochemical Journal 140, 253263.

Bradford, M. M. (1976). A rapid and sensitive method for the quantitative determination of microgram quantities of protein utilizing the principle of protein-dye binding. Analytical Biochemistry 72. 248-254.

Brook, D. F. \& LARGE, P. J. (1975). Inhibition by carbon monoxide of the secondary-amine monooxygenase of Pseudomonas aminotorans and the photochemical action spectrum for its reversal. European Journal of Biochemistry 55, 601-609. 
Colby, J. \& Zaman, L. J. (1973). Trimethylamine metabolism in obligate and facultative methylotrophs. Biochemical Journal 132, 101-112.

Delaissé, J.-M., Martin, P., Verheyen-Bouvy, M.-F. \& NYNS, E.-J. (1981). Subcellular distribution of enzymes in the yeast Saccharomycopsis lipolytica, grown on $n$-hexadecane, with special reference to the $\omega$-hydroxylase. Biochimica es biophysica acta 676, 7790.

DUBIN, D. T. (1960). The assay and characterization of amines by means of 2,4-dinitrofluorobenzene. Journal of Biological Chemistry 235, 783-786.

EAdY, R. R., Jarman, R. T. \& LARGe, P. J. (1971). Microbial oxidation of amines. Partial purification of a mixed-function secondary-amine oxidase system from Pseudomonas aminotorans that contains an enzymically active cytochrome P-420-type haemoprotein. Biochemical Journal 125, 449-459.

Green, J. \& Large, P. J. (1983a). Oxidation of dimethylamine and trimethylamine in methazotrophic yeasts by microsomal mono-oxygenases sensitive to carbon monoxide. Biochemical and Biophysical Research Communications 113, 900-907.

Green, J. \& Large, P. J. (1983b). Cell-free oxidation of dimethylamine by a mono-oxygenase in the methazotrophic yeast Candida utilis. Biochemical Society Transactions 11, 786

Green, J. \& LarGe, P. J. (1984). Regulation of the key enzymes of methylated amine metabolism in Candida boidinii. Journal of General Microbiology 130 , 1947-1959.

Haywood, G. W. \& LARGE, P. J. (1981). Microbial oxidation of amines. Distribution, purification and properties of two primary-amine oxidases from the yeast Candida boidinii grown on amines as sole nitrogen source. Biochemical Journal 199, 187-201.

HLAvica, P. (1982). Biological oxidation of nitrogen in organic compounds and disposition of $\mathbf{N}$-oxidized products. CRC Critical Reviews of Biochemistry 12. 39-101.

HOLLEY, R. A. \& KIDBY, D. K. (1973). Role of vacuoles and vesicles in extracellular enzyme secretion from yeast. Canadian Journal of Microbiology 19, 113-117

Hou, C. T., Patel, R. N. \& Barnabe, N. (1982). Identification of an NADH-linked formaldehydereducing enzyme from methanol-grown Pichia pastoris NRRL Y-7556. FEMS Microbiology Letters 15 $159-163$.

huang, A. H. C., Trelease, R. N. \& Moore, T. S., JR (1983). Plant Peroxisomes, pp. 87-155. New York Academic Press.

Jenxins, R. O., Cartledge, T. G. \& Lloyd, D. (1983). Subcellular fractionation of Candida stellatoidea after growth with glucose or $n$-hexadecane. Journal of General Microbiology 129, $1171-1185$.

KäPPELI, O., SAUER, M. \& FIEChTER, A. (1982) Convenient procedure for the isolation of highly enriched, cytochrome P-450-containing microsomal fraction from Candida tropicalis. Analytical Biochem. istry 126. 179-182.

Kärenlampi, S. O., Marin, E. \& HänNinen, O. O. P (1980). Occurrence of cytochrome P-450 in yeasts. Journal of General Microbiology 120, 529-533.

LARGE, P. J. (1981). Microbial growth on methylated amines. In Microbial Growih on $C_{1}$ Compounds Proceedings of Third International Simposium, pp
55-69. Edited by H. Dalton. London: Heyden \& Son.

LARGe, P. J. \& GReEN, J. (1984). Oxidation of mono-, di- and trimethylamine by methazotrophic yeasts: properties of the microsomal and peroxisomal enzymes involved and comparison with bacterial systems. In Microbial Growth on $C_{1}$ Compounds. Proceedings of Fourth International Symposium. Edited by R. L. Crawford. Washington: American Society for Microbiology (in the Press).

LARGE, P. J. \& MCDougali, H. (1975). An enzymic method for the microestimation of trimethylamine. Analytical Biochemistry 64, 304-310.

Large, P. J., Eady, R. R. \& Murden, D. J. (1969). An enzymic method for the microestimation of methylamine, ethylamine, and $n$-propylamine. Analytical Biochemistry 32, 402-407.

LLOYD, D. (1974). The Mitochondria of Micro-organisms, pp. 64-81. London: Academic Press.

Meiberg, J. B. M. \& Harder, W. (1978). Aerobic and anaerobic metabolism of trimethylamine, dimethylamine and methylamine in Hyphomicrobium $X$. Journal of General Microbiology 106, 265-276.

Nash, T. (1953). The colorimetric estimation of formaldehyde by means of the Hantzsch reaction. Biochemical Journal 55, 416-421.

Osumi, M., Miwa, N., Teranishi, Y., Tanaka, A. \& FUKUI, S. (1975). Development of microbodies in Candida tropicalis during incubation in a $n$-alkane medium. Archices of Microbiology 103, 1-11.

Pettit, F. H., Orme-Johnson, W. \& Ziegler, D. M. (1964). The requirement for flavin adenine dinucleotide by a liver microsomal oxygenase catalyzing the oxidation of alkylaryl amines. Biochemical and Biophysical Research Communicarions 16, 444-448.

RoBinson, J. \& COOPER, J. M. (1970). Method of determining oxygen concentrations in biological media, suitable for calibration of the oxygen electrode. Analytical Biochemistry 33, 390-399.

SAHM, H., ROGgENKAMP, R., WAgNeR, F. \& HINKELMANN, W. (1975). Microbodies in methanol-grown Candida boidinii. Journal of General Microbiology 88, 218-222.

Sawicki, E., Hauser, T. R., Stanley, T. W. \& ELBERT, W. (1961). The 3-methyl-2-benzothiazolone hydrazone test. Sensitive new methods for the detection, rapid estimation and determination of aliphatic aldehydes. Analytical Chemistry 33, 93-96.

Shaltiel, S. \& ER-El. Z. (1973). Hydrophobic chromatography: use for purification of glycogen synthetase. Proceedings of the National Academy of Sciences of the United States of America 70, 778781

Tanaka, A., Yasuhara, S., Kawamoto, S., Fukui, S. \& OsUMI, M. (1976). Development of microbodies in the yeast Kloeckera growing on methanol. Journal of Bacteriology 126. 919-927.

Tipton, K. F. (1980). Monoamine oxidase. In Enzymatic Basis of Detoxication, vol. 1, pp. 355-370. Edited by W. B. Jakoby. New York: Academic Press.

VAN DiJKen, J. P. \& Bos. P. (1981). Utilization of amines by yeasts. Archires of Microbiology 128, 320324.

Veenhuts, M., Van Dijen, J. P. \& Harder, W. (1980). A new method for the cytochemical demon- 
stration of phosphatase activities in yeasts based on the use of cerous ions. FEMS Microbiology Letters 9. 285-291.

Veenhuis, M., Van Dijken, J. P. \& Harder, W. (1983). The significance of peroxisomes in the metabolism of one-carbon compounds in yeasts. Adtances in Microbial Physiology 24, 1-82.

Yamada, H., Kishimoto, N. \& Kumagal, H. (1976). Metabolism of $\mathrm{N}$-substituted amines by yeasts. Journal of Fermentation Technology 54, 726-737.

Yamada, T., Tanaka, A. \& FukUi, S. (1982). Properties of catalase purified from whole cells and peroxisomes of n-alkane-grown Candida tropicalis. European Journal of Biochemistry 125, 517-521.

ZATMAN, L. J. (1981). A search for patterns in methylotrophic pathways. In Microbial Growth on $C_{1}$ Compounds. Proceedings of Third International Sym- posium, pp. 42-54. Edited by H. Daiton. London: Heyden \& Son.

ZWART, K. B. H HARDER, W. (1983). Regulation of the metabolism of some alkylated amines in the yeasts Candida utilis and Hansenula polymorpha. Journal of General Microbiology 129, 3157-3169.

ZWart, K., Veenhuls, M., Van DiJken, J. P. \& Harder, W. (1980). Development of amine-oxidasecontaining peroxisomes in yeasts during growth on glucose in the presence of methylamine as the sole source of nitrogen. Archices of Microbiology 126. 117 126.

Zwart, K. B., Veenhuis, M., Plat, G. \& Harder, W. (1983). Characterization of glyoxysomes in yeast and their transformation into peroxisomes in response to changes in environmental conditions. Archires of Microbiology 136, 28-38. 